\title{
Raising the bar: a story of bean-to-bar chocolate production in New Zealand
}

\author{
Arno Sturny
}

\begin{abstract}
Arno is a recent Master in Gastronomy graduate from the Auckland University of Technology (AUT). He holds the role of senior lecturer in culinary arts at the School of Hospitality and Tourism, AUT, where he teaches in the second year of the Diploma in Pâtisserie. His research interests include the wider field of baking, pâtisserie and confectionery, recently looking at the involvement of New Zealand at international pâtisserie competitions and the importance of bread in New Zealand.
\end{abstract}

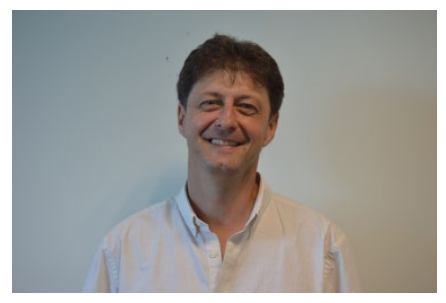

Chocolate is considered one of the most gratifying confections there is, and this holds as true in New Zealand as elsewhere in the world.

Evidence of this high interest in chocolate in New Zealand is demonstrated in the arrival of small artisanal bean-to-bar chocolate makers in the early 2000s; the voting of Whittaker's as New Zealand's single most trusted brand for eight years running (Reader's Digest New Zealand's Most Trusted Brand) [1]; the reporting on the economic, social and cultural impacts of the closure of the Cadbury chocolate factory in Dunedin [2]; and the opening of the first fair trade chocolate factory, Sweet Justice Chocolate Factory, in Christchurch by Trade Aid New Zealand [3].

These examples also demonstrate a clear transformation within New Zealand's commercial chocolate production, reflecting worldwide changes in multinational confectionery companies but also the emergence of artisanal production that directly addresses issues of sustainability and transparency [4, 5].

While broader culinary traditions in New Zealand have been welldocumented, the food history of chocolate production has not yet been explored. Consequently, this study explored the history of chocolate production in New Zealand, with a specific focus on bean-to-bar products [6].

The study, based on a narrative history and interviews with current bean-tobar chocolate makers in New Zealand, traced the history of bean-to-bar chocolate production in New Zealand. This process allowed for a multi-faceted reconstruction and interpretation of historical data to help understand various transformations within New Zealand's chocolate industry, an industry long dominated by multinational companies such as Cadbury and Nestlé. This domination by overseas companies has recently been challenged by the emergence of small artisanal bean-to-bar chocolate makers and the rise of local chocolate company, Whittaker's.

Among the key findings was evidence of the maturing of the local chocolate industry to the point where it is clear that New Zealand-made chocolate is now widely viewed and trusted by local consumers as a high-quality product. This trust extends to both the current strong player in the market, Whittaker's, and equally to smaller artisanal bean-to-bar chocolate makers, a confidence in product comparable to the New Zealand craft beer industry and the more wellestablished wine industry. 
The research also finds that the emergence of more artisanal bean-to-bar chocolate makers, and their focus on more transparency around the production of chocolate, reflects similar trends overseas. The findings highlight the fragile structure surrounding growth and sustainability in the chocolate production industry, with the view that closer ties should be formed with New Zealand's Pacific cacao-growing neighbours.

The findings point to the need for additional research around the history of food in New Zealand, an area of study often undervalued in academia [7]. The findings of the research are timely as they highlight opportunities for the industry to place current worldwide sustainability concerns in perspective with a view to the future - a future that New Zealand chocolate manufacturers cannot avoid.

The historical archival data captured together with the contemporary voices of New Zealand's new generation of chocolate makers combine to tell a story of creativity and competition.

The original research this article is based on can be accessed here:

https://openrepository.aut.ac.nz/bitstream/handle/10292/12970/SturnyA.pdf?sequence=3 \&isAllowed $=\mathrm{y}$

\section{Corresponding author}

Arno Sturny can be contacted at: arno.sturny@aut.ac.nz

\section{References}

(1) Trusted Brands New Zealand 2019. Most Trusted.

http://www.trustedbrands.co.nz/default.asp\#mostTrusted (accessed Jun 1, 2019).

(2) Cadbury's Dunedin Factory Faces Closure, 350 Jobs on the Line. The New Zealand Herald, Feb 16, 2017.

https://www.nzherald.co.nz/business/news/article.cfm?c id=3\&objectid=11801779 (accessed Jun 2, 2019).

(3) Trade Aid. The Sweet Justice Chocolate Factory. https://www.tradeaid.org.nz/trade/the-sweet-justice-chocolate-factory/ (accessed Mar 24, 2019).

(4) Fountain, A.; Huetz-Adams, F. 2018 Cocoa Barometer; 2018.

http://www.cocoabarometer.org/cocoa barometer/Download files/2018\%20Cocoa $\% 20$ Barometer\%20180420.pdf (accessed Oct 13, 2018).

(5) Squicciarini, M. P.; Swinnen, J. F. M. The Economics of Chocolate; Oxford University Press: Oxford, U.K., 2016.

(6) Sturny, A. Raising the Bar: A Story of Bean-to-Bar Chocolate Production in New Zealand; Master's Thesis, Auckland University of Technology, New Zealand, 2018. https://openrepository.aut.ac.nz/bitstream/handle/10292/12970/SturnyA.pdf?sequence =3\&isAllowed=y (accessed Nov 25, 2019).

(7) Belasco, W. G. Food Matters: Perspectives on an Emerging Field. In Food Nations: Selling Taste in Consumer Societies; Belasco, W., Scranton, P., Eds.; Taylor \& Francis: London, 2002, pp 1-22. https://www.researchgate.net/publication/239586863 (accessed Jun 15, 2019). 